\title{
Yield performance of some transplant aman rice varieties as influenced by different levels of nitrogen
}

\author{
M. T. Jisan, S. K. Paul ${ }^{*}$ and M. Salim \\ Department of Agronomy, Bangladesh Agricultural University, Mymensingh-2202, Bangladesh \\ *E-mail: skpaull@gmail.com
}

\begin{abstract}
The experiment was carried out during the period of June to November 2013 at the Agronomy Field Laboratory, Bangladesh Agricultural University, Mymensingh with a view to examine the yield performance of some transplant aman rice varieties as influenced by different levels of nitrogen. The experiment consisted of four varieties viz. BRRI dhan49, BRRI dhan52, BRRI dhan56, BRRI dhan57 and four levels of $\mathrm{N}$ viz. 0, 46, 60 and $75 \mathrm{~kg}^{-1}$. The experiment was laid out in a randomized complete block design with three replications. Variety, levels of $\mathrm{N}$ and their interactions exerted significant influence on yield contributing characters and yield of transplant aman rice. Among the varieties, BRRI dhan52 produced the tallest plant $(117.20 \mathrm{~cm})$, highest number of effective tillers hill ${ }^{-1}(11.28)$, grains panicle $^{-1}(121.5)$ and 1000-grain weight $(23.65 \mathrm{~g})$ whereas the lowest values of these parameters were produced by BRRI dhan57. Highest grain yield (5.69 $\left.\mathrm{t} \mathrm{ha}^{-1}\right)$ was obtained from BRRI dhan52 followed by BRRI dhan49 (5.15 t ha $\left.{ }^{-1}\right)$ and the lowest one $\left(4.25 \mathrm{t} \mathrm{ha}^{-1}\right)$ was obtained from BRRI dhan57. In case of $\mathrm{N}$, the tallest plant $(111.70 \mathrm{~cm})$, highest number of total tillers hill ${ }^{-1}$ (12.34), grains panicle ${ }^{-1}(133.6), 1000$-grain weight $(24.55 \mathrm{~g})$ and grain yield $\left(5.64 \mathrm{t} \mathrm{ha}^{-1}\right)$ were obtained from $75 \mathrm{~kg} \mathrm{~N} \mathrm{ha}^{-1}$ and the lowest values were obtained from control. BRRI dhan52 fertilized with $75 \mathrm{~kg}$ $\mathrm{N}$ ha ${ }^{-1}$ showed best performance with respect to all the parameters studied. The overall results suggest that BRRI dhan52 should be fertilized with $75 \mathrm{~kg} \mathrm{~N} \mathrm{ha}^{-1}$ for getting higher yield under the agro-climatic condition of BAU.
\end{abstract}

Keywords: Variety, Nitrogen, Yield performance, Transplant Aman rice

\section{Introduction}

Rice is the most important food crop of the world and the staple food of more than 3 billion people of the world's population. Rice is grown in more than a hundred countries with a total harvested area of about 160 million hectares, producing more than 700 million tons every year (IRRI, 2013). Nitrogen is a key nutrient element which plays a vital role in vegetative growth, development of yield components and yield of rice (BRRI, 1990). Efficient fertilizer management gives higher yield of crop and reduces fertilizer cost (Hossain and Islam, 2006). Rice is grown in Bangladesh in three distinct rice growing seasons namely Aus, Aman and Boro. Among these seasons, Aman rice covers the area of 5.66 million hectares with a production of 13.3 million tons (AIS, 2012). But the yield of transplant Aman rice unit ${ }^{-1}$ area is much lower in our country as compared to other rice growing countries of the world. It is mainly due to selection of potential varieties and judicious application of fertilizers. Selection of potential variety, planting in appropriate method and application of optimum amount of nutrient elements can play an important role to increase the rice yield and national income. Nitrogen management is another important factor that influences the growth, development, yield and yield components of transplanted rice significantly. Balanced fertilization ensures the plant to grow properly with their aerial and underground parts and help to increase the dry matter of the plant. Application of less or more fertilizer than the optimum are not economic i.e., both of this situation give lower yield. So fertilizer application in right time in right dose and in right form has to be ensured. Nitrogen use efficiency for rice crop largely ranges between $25 \%$ and $35 \%$ and seldom exceeds 50\% (Singh et al. 1999; Thakur, 1999). Urea is an important source of nitrogen and has great impact for increasing the nitrogen use efficiency and yield of rice. It increases absorption rate, improves soil health and ultimately increases rice yield. It is known that the response of crops to nitrogen varies due to variety. A suitable combination of variety and level of nitrogen is necessary for better yield. Therefore, the present study was conducted to evaluate the yield performance of some transplant aman rice varieties as influenced by different levels of nitrogen.

\section{Materials and Methods}

The experiment was carried out at the Agronomy Field Laboratory, Bangladesh Agricultural University, Mymensingh during June to November 2013 to study the yield performance of some transplant aman rice varieties as influenced by different levels of nitrogen. The experiment field was a medium high land having silty clay loam having $\mathrm{pH}$ 6.5. The experiment comprised four rice varieties viz. BRRI dhan49, BRRI dhan52, BRRI dhan56, BRRI dhan57 and four levels of $\mathrm{N}$ viz. $0,46,60$ and $75 \mathrm{~kg} \mathrm{ha}^{-1}$. The experiment was laid out in a randomized complete block design with three replications. The size of unit plot was $4.0 \mathrm{~m} \times 2.5 \mathrm{~m}$. Before raising seeds in the nursery, seeds were water soaked for 24 hours and then taken out of water and packed in the gunny bags for sprouting. The seeds sprouted after 72 hours. 
For raising seedlings a piece of high land was selected. Sprouted seeds were sown in the nursery bed on 20 June 2013. Proper care was taken to raise seedlings in the nursery bed. Thirty days old seedlings were transplanted on 18 July 2013 in the main field with 3 seedlings hill ${ }^{-1}$ maintaining spacing at $25 \mathrm{~cm} \times$ $15 \mathrm{~cm}$. The experimental land was prepared by power tiller and cross ploughing with a country plough and leveled by laddering. Weeds and stubble of previous crop were removed from individual plots and finally plots were leveled properly. TSP, MoP, gypsum, and zinc sulphate were applied @ 600g, $480 \mathrm{~g}, 360 \mathrm{~g}$ and $60 \mathrm{~g}$ in each plot during the final land preparation. Urea was applied as per treatment in three equal splits at 15,30 and 45 days after transplanting (DAT). Other intercultural operations were done as and when required. Four hills were randomly selected (excluding boarder hills and central $1 \mathrm{~m} \times$ $1 \mathrm{~m})$ prior to harvest to record the data on crop characters and yield contributing characters. The crop of individual plots was separately harvested at full maturity. Data on plant height, number of total and effective tillers hill ${ }^{-1}$, panicle length, number of total spikelets panicle ${ }^{-1}$, number of grains panicle ${ }^{-1}$, and weight of 1000 -grain were collected from five sample plants of each plot. The grain and straw yield for each plot were recorded after proper threshing, cleaning and drying in sun. The collected data were statistically analyzed and mean differences were compared by Duncan's New Multiple Range Test (DMRT) (Gomez and Gomez, 1984).

\section{Results and Discussion}

\section{Varietal performance}

Yield contributing characters and yield of transplant aman rice were significantly influenced by variety (Table 1). BRRI dhan52 produced the tallest plant $(117.20 \mathrm{~cm})$ followed by BRRI dhan56 $(111.6 \mathrm{~cm})$ and BRRI dhan57 $(106.9 \mathrm{~cm})$ while the shortest one $(101.30 \mathrm{~cm})$ was recorded from BRRI dhan49. These differences are mostly due to the genetic variation among the varieties. These results are consistent to those of Om et al. (1998), Khisha (2002) and Rahman (2003) who recorded variable plant height among the varieties. The highest number of total tillers hill ${ }^{-1}(12.39)$ and effective tillers hill ${ }^{-1}(11.28)$ were found in BRRI dhan52 whereas the lowest values were counted in BRRI dhan57. The variation in number of tillers hill $^{-1}$ as assessed might be due to varietal characters. Nuruzzaman et al. (2000) noticed that number of total tillers hill ${ }^{-1}$ differed among the varieties. BRRI dhan52 produced the highest number of total spikelets panicle $^{-1}(155.20)$ and the lowest number of total spikelets panicle ${ }^{-1}(118.80)$ was obtained from BRRI dhan57. BRRI dhan52 produced the highest number of grains panicle ${ }^{-1}(121.5)$ and the heaviest gram $(23.65 \mathrm{~g})$ while the lowest number of grams and lighest grain $(20.52 \mathrm{~g})$ was obtained from BRRI dhan57. BRRI dhan52 gave the highest grain yield $\left(5.69 \mathrm{t} \mathrm{ha}^{-1}\right)$, followed by BRRI dhan49 $\left(5.15 \mathrm{t} \mathrm{ha}^{-1}\right)$ while the lowest grain yield $\left(4.25 \mathrm{t} \mathrm{ha}^{-1}\right)$ was harvested from BRRI dhan57. Varietal differences regarding grain yield was reported elsewhere (Patel, 2000; Khisha, 2002; Tyeb et al. 2013 and Islam et al. 2014). Straw yield showed similar trend as like as grain yield. The grain and straw yield increasement of BRRI dhan52 over BRRI dhan57 were (33.88 \%) and (18.2\%) respectively. The highest harvest index (45.48 \%) was recorded from BRRI dhan52 and the lowest one (42.77\%) was obtained from BRRI dhan57. Tyeb et al. (2013) reported that variety has significant influence on harvest index.

Table 1. Effect of variety on yield and yield attributes of transplant aman rice

\begin{tabular}{|c|c|c|c|c|c|c|c|c|c|c|c|}
\hline Variety & $\begin{array}{l}\text { Plant } \\
\text { height } \\
(\mathrm{cm})\end{array}$ & \begin{tabular}{|c|} 
Total \\
tillers hill-1 \\
(No.)
\end{tabular} & $\begin{array}{l}\text { Effective } \\
\text { tillers hill-1-1 } \\
\text { (No.) }\end{array}$ & $\begin{array}{c}\text { Total } \\
\text { spikelets } \\
\text { panicle-1 }^{-1} \\
\text { (No.) } \\
\end{array}$ & $\begin{array}{l}\text { Grains } \\
\text { panicle-1 } \\
\text { (No.) }\end{array}$ & $\begin{array}{l}\text { 1000-grain } \\
\text { weight (g) }\end{array}$ & $\begin{array}{l}\text { Grain } \\
\text { yield } \\
\text { (t ha-1) }\end{array}$ & $\begin{array}{c}\text { Grain yield } \\
\text { increasement } \\
\text { over BRRI } \\
\text { dhan57 (\%) } \\
\end{array}$ & $\begin{array}{c}\text { Straw } \\
\text { yield } \\
\left(\mathrm{t} \mathrm{ha} \mathrm{a}^{-1}\right)\end{array}$ & $\begin{array}{c}\text { Straw yield } \\
\text { increasement } \\
\text { over BRRI } \\
\text { dhan57 (\%) }\end{array}$ & $\begin{array}{c}\text { Harvest } \\
\text { index } \\
(\%)\end{array}$ \\
\hline BRRI dhan49 & 101.30d & $11.19 b$ & $9.55 b$ & $127.50 \mathrm{c}$ & $95.29 \mathrm{C}$ & $22.90 \mathrm{~b}$ & $5.15 b$ & 21.17 & $6.53 b$ & 8.08 & $44.06 \mathrm{~b}$ \\
\hline BRRI dhan52 & $117.20 \mathrm{a}$ & $12.39 a$ & $11.28 a$ & $155.20 \mathrm{a}$ & $121.50 \mathrm{a}$ & $23.65 a$ & $5.69 a$ & 33.88 & $6.73 a$ & 18.2 & $45.48 a$ \\
\hline BRRI dhan56 & $111.60 \mathrm{~b}$ & $9.53 c$ & $8.06 \mathrm{c}$ & $147.70 \mathrm{~b}$ & $108.00 \mathrm{~b}$ & $21.50 \mathrm{c}$ & $4.88 \mathrm{c}$ & 14.82 & $6.15 \mathrm{c}$ & 14.76 & $44.01 \mathrm{~b}$ \\
\hline BRRI dhan57 & $106.90 \mathrm{c}$ & $8.94 d$ & $6.74 d$ & $118.80 \mathrm{~d}$ & $77.75 d$ & $20.52 d$ & $4.25 d$ & - & $5.69 d$ & - & $42.77 \mathrm{c}$ \\
\hline Level of significance & ** & ** & ** & $\star \star *$ & $\star \star *$ & $\star \star$ & $* *$ & - & $\star \star *$ & - & ** \\
\hline $\mathrm{CV}(\%)$ & 5.01 & 3.95 & 4.66 & 6.23 & 8.42 & 3.10 & 4.45 & - & 1.91 & - & 2.44 \\
\hline
\end{tabular}

In a column, figures having dissimilar letters differ significantly as per Duncan's Multiple Range Test (DMRT).

** = Significant at $1 \%$ level of probability 


\section{Effect of level of nitrogen}

Application of $\mathrm{N}$ significantly influenced the yield and yield attributes of transplant aman rice (Table 2). Plant height increased with the increasing rates of $\mathrm{N}$. The tallest plant $(111.70 \mathrm{~cm})$ was recorded at $60 \mathrm{~kg}$ $\mathrm{N} \mathrm{ha}^{-1}$ which was statistically identical to $75 \mathrm{~kg} \mathrm{~N}^{-1}$ and the shortest one $(105.4 \mathrm{~cm})$ was recorded from control $\left(0 \mathrm{~kg} \mathrm{~N} \mathrm{ha}^{-1}\right)$ treatment. The highest number of total tillers hill ${ }^{-1}(12.34)$ and effective tillers (11.27) were recorded from $75 \mathrm{~kg} \mathrm{~N} \mathrm{ha}^{-1}$ and the lowest one (8.48) was recorded in control plots $\left(0 \mathrm{~kg} \mathrm{~N} \mathrm{ha}^{-1}\right)$. The highest number of total spikelets panicle ${ }^{-1}(158.10)$ and grains panicle ${ }^{-1}(133.60)$ were obtained at 75 $\mathrm{kg} \mathrm{N} \mathrm{ha}^{-1}$ followed by $60 \mathrm{~kg} \mathrm{~N} \mathrm{ha}^{-1}$ and the lowest values of total spikelets panicle ${ }^{-1}(116.00)$ and grains panicle $^{-1}(62.80)$ were recorded in control plots $\left(0 \mathrm{~kg} \mathrm{~N} \mathrm{ha}^{-1}\right)$. Nitrogen helps in proper filling of seeds which resulted higher number of grains panicle ${ }^{-1}$. Mendhe et al., (2002) reported that the number of grains panicle $^{-1}$ increased significantly with increments in level of $\mathrm{N}$ which was also reported elsewhere (Salahuddin et al., 2009; Mendhe et al., 2002). The heaviest grains (24.55 g) was obtained at $75 \mathrm{~kg} \mathrm{~N}^{-}$ ${ }^{1}$ and the lighest grain (19.45) was recorded from control $\left(0 \mathrm{~kg} \mathrm{~N} \mathrm{ha}^{-1}\right)$. Baligar and Ganin (2001) reported that the weight of 1000-grain increased significantly with increasing $\mathrm{N}$ levels. The highest grain $(5.64 \mathrm{t}$ ha $\left.{ }^{1}\right)$ and straw $\left(6.70 \mathrm{t} \mathrm{ha}^{-1}\right)$ yield and harvest index (45.63\%) were obtained when N was applied @ $75 \mathrm{~kg}$ $\mathrm{ha}^{-1}$ and the lowest from the control $\left(0 \mathrm{~kg} \mathrm{~N} \mathrm{ha}^{-1}\right)$ treatment. When N was applied @ $75 \mathrm{~kg} \mathrm{ha}^{-1}$ it showed $(31.77 \%)$ higher grain and (15.92 \%) higher straw yield over control treatment.

Table 2. Effects of different levels of $\mathrm{N}$ on yield and yield attributes of transplant aman rice

\begin{tabular}{|c|c|c|c|c|c|c|c|c|c|c|c|}
\hline $\begin{array}{c}\text { Level } \\
\text { of } \mathrm{N} \\
\left(\mathrm{kg} \mathrm{ha}^{-1}\right)\end{array}$ & $\begin{array}{l}\text { Plant } \\
\text { height } \\
(\mathrm{cm})\end{array}$ & $\begin{array}{c}\text { Total tillers } \\
\text { hill-1 } \\
\text { (No.) }\end{array}$ & $\begin{array}{l}\text { Effective } \\
\text { tillers hill-1 } \\
\text { (No.) }\end{array}$ & $\begin{array}{c}\text { Total spikelets } \\
\text { panicle-1 } \\
\text { (No.) }\end{array}$ & $\begin{array}{l}\text { Grains } \\
\text { panicle-1 }^{-1} \\
\text { (No.) }\end{array}$ & \begin{tabular}{|l|} 
1000-grain \\
weight $(\mathrm{g})$
\end{tabular} & $\begin{array}{l}\text { Grain } \\
\text { yield } \\
(t \text { ha-1) }\end{array}$ & $\begin{array}{c}\text { Grain yield } \\
\text { increasement } \\
\text { over BRRI } \\
\text { dhan57 (\%) }\end{array}$ & $\begin{array}{l}\text { Straw } \\
\text { yield } \\
\left(\mathrm{t}^{-1} \mathrm{a}^{-1}\right)\end{array}$ & $\begin{array}{c}\text { Straw yield } \\
\text { increasement } \\
\text { over BRRI } \\
\text { dhan57 (\%) }\end{array}$ & $\begin{array}{c}\text { Harvest } \\
\text { index } \\
(\%)\end{array}$ \\
\hline 0 & $105.40 \mathrm{~b}$ & $8.48 d$ & $6.61 \mathrm{~d}$ & $116.00 \mathrm{~d}$ & $62.80 \mathrm{~d}$ & $19.45 d$ & $4.28 d$ & - & $5.78 d$ & - & $42.38 c$ \\
\hline 46 & 108.80ab & $10.36 \mathrm{c}$ & $8.68 \mathrm{c}$ & $129.10 \mathrm{c}$ & $88.37 \mathrm{c}$ & $21.37 \mathrm{c}$ & $4.69 c$ & 9.57 & $6.02 \mathrm{c}$ & 4.15 & $43.75 b$ \\
\hline 60 & $111.70 \mathrm{a}$ & $11.37 \mathrm{~b}$ & $9.99 \mathrm{~b}$ & $146.10 \mathrm{~b}$ & $117.80 \mathrm{~b}$ & $23.20 \mathrm{~b}$ & $5.35 b$ & 25 & $6.39 \mathrm{~b}$ & 10.55 & $45.33 a$ \\
\hline 75 & $111.10 \mathrm{a}$ & $12.34 a$ & $11.27 \mathrm{a}$ & $158.10 \mathrm{a}$ & $133.60 a$ & $24.55 a$ & $5.64 a$ & 31.77 & $6.70 \mathrm{a}$ & 15.92 & $45.63 a$ \\
\hline $\begin{array}{c}\text { Level of } \\
\text { significance }\end{array}$ & * & ** & ** & ** & ** & ** & ** & - & ** & - & *夫 \\
\hline CV (\%) & 5.01 & 3.95 & 4.66 & 6.23 & 8.42 & 3.10 & 4.45 & - & 1.91 & - & 2.44 \\
\hline
\end{tabular}

In a column, figures having dissimilar letters differ significantly as per Duncan's Multiple Range Test (DMRT).

** $=$ Significant at $1 \%$ level of probability

* $=$ Significant at $5 \%$ level of probability

\section{Interaction effect of variety and level of nitrogen}

Interaction of variety and level of $\mathrm{N}$ showed significant influence on crop characters, yield contributing characters and yield of transplant aman rice (Table 3). BRRI dhan52 fertilized with $75 \mathrm{~kg} \mathrm{~N}^{-1}$ produced the highest number of total tillers hill ${ }^{-1}(14.03)$ and the lowest one (7.09) was obtained in the interaction of BRRI dhan57 and control $\left(0 \mathrm{~kg} \mathrm{~N} \mathrm{ha}^{-1}\right)$. The highest number of effective tillers hill ${ }^{-1}$ (13.05) was counted in the treatment combination of BRRI dhan52 fertilized with $75 \mathrm{~kg} \mathrm{~N}^{-1}$. The lowest one (5.15) was produced by the interaction between BRRI dhan57 and control $\left(0 \mathrm{~kg} \mathrm{~N}^{-1}\right)$. Interaction between BRRI dhan52 and $75 \mathrm{~kg} \mathrm{~N} \mathrm{ha}^{-1}$ was found to be the best in respect of total spikelets panicle ${ }^{-1}$ (190.9) and number of grains panicle ${ }^{-1}$ (171.4). The lowest number of total spikelets panicle ${ }^{-1}(99.90)$ and grains panicle $^{-1}(50.94)$ were obtained from the interaction between BRRI dhan49 and control $\left(0 \mathrm{~kg} \mathrm{~N} \mathrm{ha}{ }^{-1}\right)$ which was statistically identical (56.50) with the interaction of BRRI dhan57 and control. The highest 1000-grain weight $(27.39 \mathrm{~g})$ was obtained from BRRI dhan52 fertilized with $75 \mathrm{~kg} \mathrm{~N}^{-1}$. The lowest 1000-grain weight $(17.99 \mathrm{~g})$ was obtained from the interaction of BRRI dhan57 with control $\left(0 \mathrm{~kg} \mathrm{~N} \mathrm{ha}^{-1}\right)$ which was statistically identical (18.62) by the interaction between BRRI dhan56 and control $\left(0 \mathrm{~kg} \mathrm{~N}^{-1}\right)$ and the interaction between BRRI dhan57 and $46 \mathrm{~kg} \mathrm{~N} \mathrm{ha}^{-1}(19.00)$. The highest grain $\left(6.6 \mathrm{t} \mathrm{ha}^{-1}\right)$ and straw yield $\left(7.51 \mathrm{t} \mathrm{ha}^{-1}\right.$ ) were recorded in the treatment combination of BRRI dhan52 and $75 \mathrm{~kg} \mathrm{~N} \mathrm{ha}^{-1}$ followed by BRRI dhan56 fertilized with $75 \mathrm{~kg} \mathrm{~N} \mathrm{ha}^{-1}$. The lowest grain $\left(3.52 \mathrm{t} \mathrm{ha}^{-1}\right)$ and straw $\left(5.08 \mathrm{t} \mathrm{ha}^{-1}\right)$ yield were found in the treatment combination of BRRI dhan57 and control $\left(0 \mathrm{~kg} \mathrm{~N} \mathrm{ha}^{-1}\right)$ treatment. 
Table 3. Interaction effect of variety and level of $\mathrm{N}$ on yield and yield attributes of transplant aman rice

\begin{tabular}{|c|c|c|c|c|c|c|c|}
\hline $\begin{array}{c}\text { Interaction (Variety } \times \text { level of } \\
\text { nitrogen) }\end{array}$ & $\begin{array}{l}\text { Total tillers hill-1 } \\
\text { (No.) }\end{array}$ & $\begin{array}{l}\text { Effective tillers } \\
\text { hill-1 (No.) }\end{array}$ & $\begin{array}{l}\text { Total spikelets } \\
\text { panicle-1 (No.) }^{-1}\end{array}$ & $\begin{array}{l}\text { Grains panicle-1 } \\
\text { (No.) }\end{array}$ & $\begin{array}{l}\text { 1000-grain } \\
\text { weight }(g)\end{array}$ & $\begin{array}{l}\text { Grain yield } \\
\left(\mathrm{t} \mathrm{ha}^{-1}\right)\end{array}$ & $\begin{array}{l}\text { Straw yield } \\
\left(\mathrm{t} \mathrm{ha}^{-1}\right)\end{array}$ \\
\hline $\mathrm{V}_{1} \times \mathrm{N}_{0}$ & 8.45hi & $6.73 i j$ & $108.40 \mathrm{gh}$ & $50.94 \mathrm{i}$ & $20.80 \mathrm{~g}$ & $4.71 \mathrm{fg}$ & 6.32ef \\
\hline $\mathrm{V}_{1} \times \mathrm{N}_{1}$ & 10.35 ef & $8.77 \mathrm{fg}$ & $116.00 \mathrm{fg}$ & $66.44 \mathrm{gh}$ & $22.69 \mathrm{de}$ & 5.08ef & $6.50 \mathrm{de}$ \\
\hline $\mathrm{V}_{1} \times \mathrm{N}_{2}$ & $11.52 \mathrm{c}$ & $10.35 d$ & $122.40 \mathrm{efg}$ & 91.14ef & $23.64 \mathrm{bcd}$ & 5.32cde & $6.60 \mathrm{~cd}$ \\
\hline $\mathrm{V}_{1} \times \mathrm{N}_{3}$ & $13.25 b$ & $12.17 \mathrm{~b}$ & $128.40 \mathrm{ef}$ & 102.50def & $24.48 b$ & $5.49 \mathrm{bcd}$ & $6.69 \mathrm{bcd}$ \\
\hline $\mathrm{V}_{2} \times \mathrm{N}_{0}$ & 10.33ef & $8.33 g$ & 124.70ef & $73.17 \mathrm{~g}$ & $20.39 g$ & 4.94efg & $6.22 f$ \\
\hline $\mathrm{V}_{2} \times \mathrm{N}_{1}$ & $12.78 \mathrm{~b}$ & $11.07 \mathrm{c}$ & $130.90 \mathrm{ef}$ & $91.24 f$ & 22.61de & $5.25 \mathrm{de}$ & $6.38 \mathrm{ef}$ \\
\hline $\mathrm{V}_{2} \times \mathrm{N}_{2}$ & $13.18 \mathrm{~b}$ & $11.67 \mathrm{bc}$ & $174.00 \mathrm{~b}$ & $150.10 \mathrm{~b}$ & $24.19 b c$ & $5.72 \mathrm{bc}$ & $6.78 b c$ \\
\hline $\mathrm{V}_{2} \times \mathrm{N}_{3}$ & $14.03 a$ & $13.05 \mathrm{a}$ & $190.90 \mathrm{a}$ & $171.40 \mathrm{a}$ & $27.39 a$ & $6.60 a$ & $7.51 \mathrm{a}$ \\
\hline $\mathrm{V}_{3} \times \mathrm{N}_{0}$ & $8.04 i$ & $6.21 j$ & $130.90 \mathrm{ef}$ & 70.61gh & $18.62 \mathrm{~h}$ & $3.95 h$ & $5.51 \mathrm{~h}$ \\
\hline $\mathrm{V}_{3} \times \mathrm{N}_{1}$ & $9.02 \mathrm{gh}$ & 7.29hi & $148.70 \mathrm{~cd}$ & $107.90 d$ & $21.19 f g$ & $4.27 \mathrm{~h}$ & $5.65 \mathrm{gh}$ \\
\hline $\mathrm{V}_{3} \times \mathrm{N}_{2}$ & $10.13 f$ & $8.61 \mathrm{fg}$ & $152.80 \mathrm{c}$ & $123.50 \mathrm{c}$ & $22.86 \mathrm{de}$ & $5.54 \mathrm{bcd}$ & $6.60 \mathrm{~cd}$ \\
\hline $\mathrm{V}_{3} \times \mathrm{N}_{3}$ & $10.95 \mathrm{cde}$ & 9.75de & $158.40 c$ & $130.00 \mathrm{c}$ & 23.32bcde & $5.73 b$ & $6.84 \mathrm{~b}$ \\
\hline $\mathrm{V}_{4} \times \mathrm{N}_{0}$ & $7.09 \mathrm{j}$ & $5.15 \mathrm{k}$ & $99.90 \mathrm{~h}$ & 56.50hi & $17.99 \mathrm{~h}$ & $3.52 i$ & $5.08 i$ \\
\hline $\mathrm{V}_{4} \times \mathrm{N}_{1}$ & $9.293 \mathrm{~g}$ & $7.59 \mathrm{~h}$ & 120.70efg & $87.90 f$ & $19.00 \mathrm{~h}$ & $4.16 \mathrm{~h}$ & $5.53 \mathrm{~h}$ \\
\hline $\mathrm{V}_{4} \times \mathrm{N}_{2}$ & $10.66 \mathrm{def}$ & $9.31 \mathrm{ef}$ & 135.00de & 106.40de & $22.10 \mathrm{ef}$ & $4.64 \mathrm{~g}$ & $5.59 \mathrm{gh}$ \\
\hline $\mathrm{V}_{4} \times \mathrm{N}_{3}$ & $11.14 \mathrm{~cd}$ & $10.11 d$ & $154.50 \mathrm{c}$ & $130.40 \mathrm{c}$ & 22.99 cde & $4.71 \mathrm{fg}$ & $5.76 \mathrm{~g}$ \\
\hline Level of significance & ** & $\star *$ & ** & $\star \star$ & ** & ** & $\star *$ \\
\hline CV (\%) & 3.95 & 4.66 & 6.23 & 8.42 & 3.10 & 3.77 & 3.50 \\
\hline
\end{tabular}

In a column, figures having dissimilar letters differ significantly as per Duncan's Multiple Range Test ( DMRT)

$\star *=$ Significant at $1 \%$ level of probability * $=$ Significant at $5 \%$ level of probability

$\mathrm{V}_{1}=\mathrm{BRRI}$ dhan49, $\mathrm{V}_{2}=\mathrm{BRRI}$ dhan52, $\mathrm{V}_{3}=\mathrm{BRRI}$ dhan56, $\mathrm{V}_{4}=$ BRRI dhan57

$\mathrm{N}_{0}=$ Control $\left(0 \mathrm{~kg} \mathrm{~N} \mathrm{ha}^{-1}\right), \mathrm{N}_{1}=46 \mathrm{~kg} \mathrm{~N} \mathrm{ha}^{-1}, \mathrm{~N}_{2}=60 \mathrm{~kg} \mathrm{~N} \mathrm{ha}^{-1}$ and $\mathrm{N}_{3}=75 \mathrm{~kg} \mathrm{~N} \mathrm{ha}^{-1}$

From the result of this experiment, it can be concluded that, the performance of BRRI dhan52 was the best among the tested varieties. Crop fertilized with $75 \mathrm{~kg} \mathrm{~N} \mathrm{ha}^{-1}$ showed the best performance among the other nitrogen levels. BRRI dhan52 fertilized with $75 \mathrm{~kg} \mathrm{~N} \mathrm{ha}^{-1}$ appeared at the promising combination for transplant aman rice cultivation in terms of grain yield.

\section{References}

AIS (Agricultural Information Service). 2012. Krishi Dairy. Agric. Info. Service. Khamarbari, Farmgate, Dhaka. pp. 10-15.

Baligar, A.S. and Ganin, B.A. 2001. Response of rice genotypes to nitrogen level under transplanted condition in Brazil. Newsl.9 (5): 29-31.

BRRI (Bangladesh Rice Research Institute). 1990. Annual Report for 1989. Bangladesh Rice Res. Inst., Joydebpur, Gazipur, Bangladesh, BRRI Pub. No. 92. p. 9.

Gomez, K.A. and Gomez, A. A. 1984. Statistical Procedures for Agricultural Research. Intl. Rice Res. Inst., John Wiley and Sons. New York, Chichester, Brisbane, Toronto, Singapore. p. 680.

Hossain, S.M.A. and Islam, M.S. 2006. Fertilizer Management. in Bangladesh. Adv. Agron. Res. in Joydebpur, Gazipur. pp. 48-54.

Islam, M.S., Paul, S.K. and Sarkar, M.A.R. 2014. Varietal performance of modern transplant Aman rice subjected to level of nitrogen application. J.Bangladesh Agril. Univ. 12 (1) : 55-60.

IRRI (Internationals Rice Research Institute). 2013. Annual Report Int. Rice Res. Inst. Los Banos, Philippines. p. 179.

Khisha, K. 2002. An Evaluating of Madagascar System of Rice Production in Aman season with three high potential rice varieties. M.S. Thesis, Dept. Agorn., Bangladesh Agril. Univ., Mymensingh. pp. 36-98.

Mendhe, S.N., Chaudhuri, C.S., Sawaji, B.V., Farkade, B.K. and Khades, V.A. 2002. Nitrogen requirement and yield performance of promising cultures of transplanted paddy. J. Agron. 12(2): 284-288.

Nuruzzaman, M., Yamamoto, Y., Nitta, Y., Yoshida, Y., and Miyazaki. A. 2000. Varietal differences in tillering ability of fourteen Japonica and Indica rice varieties. Soil Sci. Plant Nutri. 46(2): 381-391.

Om, H., Dhiman, S.D., Nandal, D.P. and Verma, S.L. 1998. Effect of method of nursery raising and nitrogen on growth and yield of hybrid rice (Oryza sativa). Indian J. Agron. 43(1): 68-70.

Patel, J.R. 2000. Effect of water regime, variety blue green algae on rice (Oryza sativa) hybrids. Indian J. Agron. 45(1): 103-106.

Rahman, M.A. 2003. Effect of levels of urea super granules and depth of placement on the growth and yield of transplant Aman rice. M.S. Thesis, Dept. Agron., Bangladesh Agril, Univ., Mymensingh. 100 p.

Singh, G., Singh, O.P., Yadav, R.A., Singh, R.S. and Singh, B.B. 1999. Effect of N source and levels of nitrogen on grain yield, yield contributes, N-uptake, recovery and response by the deep water condition, Crop Res. 6 (2): 214-216.

Salahuddin, K.M., Chowdhury, S.H., Munira, S., Islam, M.M. and Parvin, S. 2009. Response of nitrogen and plant spacing transplanted aman rice. Bangladesh J. Agril. Res. 34(2): 279-285.

Thakur, K.M. 1999. Relative efficiency of prilled urea and modified urea fertilizer in rainfed low land rice. Indian J. Agron. 31(1): 87-90.

Tyeb, A., Paul, S.K. and Samad, M.A. 2013. Performance of variety and spacing on the yield and yield contributing characters of transplant Aman rice. J. Agrof. Environ. 7 (1): 57-60. 